\title{
The Increasing Consumer Interest in Buying Through Electronic and Endorsement Advertising Media in Tangerang City Sport Mall Shop
}

\author{
Ismayudin Yuliyzar \\ Fakultas Ekonomi dan Bisnis Universitas Muhammadiyah Tangerang \\ Jalan Perintis Kemerdekaan 1 no.33 Tangerang-Banten 15118
}

\begin{abstract}
The purpose of this study was to determine the effect of electronic media advertising and endorsement on consumer buying interest in the physical sport shop in Tangerang City Mall. The period used in this study is 2 (months) months, from July to August 2018.

This research uses a quantitative descriptive approach. The population in this study were 172 people who knew and used specs shoes as well as advertisements in online electronic media. The sampling technique used was purposive sampling and obtained a sample of 63 people. Data analysis techniques used were descriptive statistics, regression tests, correlation tests and hypothesis tests.

The results showed that partially electronic media advertising had a positive and significant effect on consumer buying interest, indicated by the count value $>t$ table $(3.779>1.999)$ and a significance of 0,000 . For the endorsement variable partially positive and significant effect on consumer buying interest is indicated by the value of $t$ arithmetic $>t$ table $(4,112>1,999)$ and a significance of 0,000 . Simultaneously electronic media advertising and endorsement had a positive and significant effect on company value, indicated by the calculated $\mathrm{F}$ value $>\mathrm{F}$ table $(16.908>3.15)$ and a significance of 0.000 . The ability of electronic media advertising and endorsement variables in explaining consumer buying interest is $25.3 \%$, as indicated by the size of the adjusted $\mathrm{R}$ square of 0.253 while the remaining $74.8 \%$ is influenced by other factors not included in the research model. With the value of the multiple linear regression equation $\mathrm{Y}=3.757+0.285 \mathrm{X} 1+0.418 \mathrm{X} 2$. The value of multiple correlation equations is 0.503 which has a moderate level of relationship intervals.
\end{abstract}

Keywords: Consumer Buyinh Interest, electronic media advertising, and Endorsement.

DOI: $10.7176 / \mathrm{JMCR} / 63-07$

Publication date: December $31^{\text {st }} 2019$

\section{INTRODUCTION}

In the era of globalization, demand has change in in all fields, a very influential change is in the field of marketing. Companies must be able to compete and survive the intense business competition, attractive and effective promotional strategies are one of the keys so that a company's products can still exist in a market. To remain competitive is not easy especially at the level of consumers is easily tempted in other brands that are more attractive products, so companies must be able to survive and continue to compete in various ways to meet the expectations according to the desires and interests of consumers.

From above, companies in running their businesses are demanded to remain creative, competitive, and innovative, especially in the field of marketing to achieve goals so that they can maintain the buying interest of old consumers and also get new customers. This is what happened in the competition in the sports shoes market in Indonesia. This business is increasingly competitive with many foreign brands and local rivals who helped enliven the sports shoes market in Indonesia.

In the sports shoes industry in Indonesia, several foreign brands still rank at the top and top the top brand awards in the sports shoes category, for example Nike, Adidas, Puma, Converse, and others. Some well-known local brands do not even make it into the top 6 chart nominations, it is evidence of the strong influence of foreign brands in Indonesia. But some still survive in the local market for example specs, league, piero, brick, and ardiles. 


\begin{tabular}{|c|c|c|}
\hline & Sport shoes & \\
\hline Merek & TBI & TOP \\
\hline Adidas & $38,2 \%$ & TOP \\
\hline Nike & $32,2 \%$ & TOP \\
\hline Converse & $36, \%$ & \\
\hline Eagle & 3,3 & \\
\hline Reebok & 3,3 & \\
\hline
\end{tabular}

Sources : www.topbrand-award.com/top-brand-survey/survey-result/top brand index 2017 fase 2

The competition between foreign brands and local competitors, specs are sports shoes products in the country that are still in interest. Since its inception, specs have been positioned as sports shoes and are always consistent in the segment and not out of focus on the vision and mission that has been made, in 2014 the specs received the 2014 Social Media award in the sport shoes category by Marketing Magazine \& Frontier because of its incessant in promoting through social media, and in 2015 received the 2015 Original Indonesia Brand Award in the Sport Shoes category by SWA Magazine which is the original Indonesian brand award in the sports shoes category, and started exporting products to South Korea in the same year (source: http // specs. id).

This is a proud achievement however in recent years began to fade due to increasingly competitive competition and local giant competitors have begun to following the market with many strategies, so consumers are more careful in gathering the information they get, companies should not be careless and must always presenting an effective marketing strategy to remain exist and survive is also in demand in the market.

One of the right strategy tools is to use promotional tools. Many things can be utilized in using promotional tools, one of which uses electronic media. The report, which was sourced inet.detik.com Tetra Pak Index 2017, which was recently launched, noted there are around 132 million internet users in Indonesia. While almost half are social media enthusiasts, or around $40 \%$. This figure increased considerably compared to 2016 the increase in internet users in Indonesia was around $51 \%$ or around 45 million users, followed by a growth of $34 \%$ active users of social media. While users who access social media via mobile are estimated at $39 \%$, this information is evidence that electronic media currently plays an important role as a source of information and consumer interaction needed to find out everything about the publication of a product that producers want to display as a means of connecting between consumers long-term benefits between companies and consumers.

In this case the specs lately are less aggressive and attractive in utilizing advertising media, local and foreign brands are more often and easily found in various online electronic media, the advertising content is also interesting, unique and futuristic modern, in other media such as television specs do not do advertisements such as other local and international brands. Therefore, the possibility of information about product specs is less stimulating to consumers who are currently using media more frequently in all their activities. Therefore the advertising strategy of electronic media specs products must be designed in such a way as to compete and attract consumers to buy.

Another effort that can be done to maintain the brand in the market is to use endorsement services, namely cooperation between popular figures or public figures with the company, using public figures as an attraction to ensure that the brand will get the most attention from the public because it has many fans and popularity from endorsers. In this case the big world brands such as adidas and Nike endorsed world footballers, for example adidas who collaborates with lionel messi, and Nike who cooperates with Cristiano Ronaldo, because every football celebrity is a representative of his fans, and fans are always eager to follow his idols so fans will buy and follow what their idols wear. We know how influential these field stars can be seen from their social media followers so that the perception of local consumers is more proud and prestigious when using products they use. The evidence is also seen from the top brand chart above that outside products still dominate the local market, specs products work with football stars who graze in the homeland such as Marko Simic, Adam Alis and Cristian Gonzales, also sponsors famous clubs such as Jakarta, Arema fc and Persipura fc to try to maneuver the local market while maintaining market share in the market. 


\section{THEORY AND LITERATURE REVIEW}

Definition of advertisement

According to Kotler and Keller (2017: 202) advertising is all forms of paid for non-personal presentations and promotions, goods, or services by clear sponsors, advertising can be a cost effective way to distribute messages, both with the aim of building brand preferences or educating person.

According to Buchari Alma (2016: 195) advertising is part of the promotion, because advertising is one way to carry out promotions. Advertising is done through certain media such as TV, radio, newspapers, magazines and so on.

Definition of endorsement

According to Terrence A Shimp (2014: 460) endorsements are figures (actors, entertainers or Population

According to Sugiyono (2016: 80) the population is a generalization area consisting of: objects or subjects that have certain qualities and characteristics determined by researchers to be studied by then drawing conclusions. The population of this study is consumers or visitors in the specs shop in Tangerang City mall as many as 172 people.

Sample

According to Sugiyono (2016: 81) the sample is part of the number and characteristics possessed by the population. If the population is large, and researchers may not study everything in the population, for example due to limited funds, manpower and time, then researchers can use samples taken from that population.

The sampling technique used in this study is nonprobability sampling according to Sugiyono (2016: 84), which is a sampling technique that does not provide equal opportunity or opportunity for each element or member of the population to be selected as a sample. Sampling was done by purposive random sampling, which is a sampling technique with certain considerations.

Method of collecting data

Data collection methods used were questionnaires. The value of the questionnaire statement is measured using a Likert scale as for the assessment as follows:

a. Strongly Agree $=5$

b. Agree $=4$

c. netral $=3$

d. Disagree $=2$

e. Strongly Disagree $=1$

Data analysis method

Validity test

According to Imam Ghozali (2017: 52) Validity test is used to measure the validity or validity of a questionnaire.

Reliability Test

Imam Ghozali (2017: 47) said that Reliability is actually a tool to measure a questionnaire which is an indicator of a variable or construct. A questionnaire can be said to be reliable or reliable if a person's answer to a statement is consistent or stable from time to time.

Multiple Regression Analysis

Multiple regression analysis is the development of a simple regression test of its usefulness, namely to predict the value of the dependent variable $(\mathrm{Y})$ if the independent variable $(\mathrm{X})$ is at least two or more.

Simple Correlation Analysis

Correlation analysis is an analysis to test how much the relationship between the Independent variable (Variable $\mathrm{X}$ ) and the Dependent variable (Variable Y). By using the Product Moment correlation coefficient approach

Coefficient of Determination (R2)

According to Imam Ghazali (2016: 95) the coefficient of determination essentially measures how far the ability of the model in explaining the variation of the dependent variable. The coefficient of determination is between zero and one. A small R2 value means that the ability of independent variables is very limited.

Partial Significance Test (t Test Statistics)

According to Imam Ghozali (2016: 97) the statistical test $t$ basically shows how far the influence of one independent variable individually in explaining the dependent variable.

Simultaneous Significance Test (Statistical Test f) 
According to Imam Ghozali (2016: 96) the F statistical test basically shows whether all independent variables namely electronic media advertising (X1) and endorsement (X2) included in the model have a joint influence on the dependent variable of consumer buying interest (Y).

\section{DISCUSSION}

Data analysis

Validity test

Validity test is used to measure the validity of a questionnaire. A questionnaire is declared valid if the statement on the questionnaire is able to reveal something that will be measured by the questionnaire by comparing the value of $r$ count with $r$ table. Based on the results of the validity test using the SPSS 25 program, all items of questionnaire statements for Electronic Media Adverts (X1), Endorsement variables (X2) and consumer buying interest show numbers above the $\mathrm{r}$ table then the statement is valid, because each statement has a calculated value $r$ greater than $r$ table.

Reliability Test

In the reliability test, if the results of Cronbach alpha are above 0.60 then the data have high reliability (Maman Abdurahman et al 2017: 56). From the results of the study note that 3 variables have values above 0.6. Electronic advertising media variable has Cronbach's Alpha of 0.877. Cronbach's Alpha Endorsement Variable is 0.855. The consumer purchase interest variable has a Cronbach's Alpha of 0.821

Regression Analysis Test Results

Simple regression analysis is an analysis involving only two variables, namely to determine the effect of variable $\mathrm{X} 1$ (electronic media advertising) on the variable Y (consumer buying interest) and variable X2 (endorsement) on the variable Y (consumer buying interest) partially,

Simple Linear Regression Test Results from Variables

Electronic Media Advertising (X1) and Consumer Purchase Interest (Y)

\begin{tabular}{|c|c|c|c|c|c|c|}
\hline \multicolumn{7}{|c|}{ Coefficients $^{\mathrm{a}}$} \\
\hline \multirow{2}{*}{\multicolumn{2}{|c|}{ Model }} & \multicolumn{2}{|c|}{$\begin{array}{l}\text { Unstandardized } \\
\text { Coefficients }\end{array}$} & \multirow{2}{*}{$\begin{array}{c}\text { Standardized } \\
\text { Coefficients } \\
\text { Beta }\end{array}$} & \multirow[b]{2}{*}{$\mathrm{T}$} & \multirow[b]{2}{*}{ Sig. } \\
\hline & & $\mathrm{B}$ & Std. Error & & & \\
\hline \multirow[t]{2}{*}{1} & (Constant) & 11,471 & 5,146 & & 2,229 &, 030 \\
\hline & $\begin{array}{l}\text { X1.Iklan_Media_Elektro } \\
\text { nik }\end{array}$ & ,516 & ,137 & ,436 & 3,779 &, 000 \\
\hline
\end{tabular}

a. Dependent Variable: Y.Minat_Beli_Konsumen

Based on calculation above here the result

$$
\mathrm{Y}=\mathbf{1 1 , 4 7 1 + 0 , 5 1 6 X}
$$

The equation above means that every time there is an increase in the variable of electronic media advertising by one unit, the consumer buying interest will increase by 0.516 for example if the variable is increased by 2 to 1.032.

Simple Linear Regression Test Results from Variables

Endorsement (X2) and Consumer Purchase Interest (Y)

\section{Coefficients $^{\mathrm{a}}$}

\begin{tabular}{|c|c|c|c|c|c|c|}
\hline \multirow{2}{*}{\multicolumn{2}{|c|}{ Model }} & \multicolumn{2}{|c|}{$\begin{array}{l}\text { Unstandardized } \\
\text { Coefficients }\end{array}$} & \multirow{2}{*}{$\begin{array}{c}\text { Standardized } \\
\text { Coefficients } \\
\text { Beta }\end{array}$} & \multirow[b]{2}{*}{$\mathrm{T}$} & \multirow[b]{2}{*}{ Sig. } \\
\hline & & $\mathrm{B}$ & Std. Error & & & \\
\hline \multirow[t]{2}{*}{1} & (Constant) & 6,843 & 5,851 & & 1,170 &, 247 \\
\hline & X2.Endoesement & ,611 & ,149 & ,466 & 4,112 &, 000 \\
\hline
\end{tabular}

a. Dependent Variable: Y.Minat_Beli_Konsumen

Sources : data process SPSS 25

Based on abover calculation here the result 


\section{$Y=6,843+0,611 X$}

The equation above means that each endorsement variable increases by one unit, the buying interest of consumers or visitors to the Tangerang City Mall Physical Sport Shop will increase by 0.611 for example if the variable is increased by 2 to 1.222 .

Multiple Linear Regression Analysis

Multiple linear regression analysis is an analysis that involves two or more independent (independent) variables on the dependent variable (dependent), in this study, to determine the effect of variable X1 (electronic media advertising) and X2 variable (endorsement) on Y variable (interest buy consumers) together or simultaneously, Following is the output table of multiple linear regression analysis using SPSS 25:

Multiple Linear Regression Test Results from Electronic Media Ad Variables (X1) and Endorsement Variables (X2) and Consumer Purchase Interest (Y)

\section{Coefficients $^{\mathrm{a}}$}

\begin{tabular}{|c|c|c|c|c|c|c|}
\hline & & \multicolumn{2}{|c|}{$\begin{array}{l}\text { Unstandardized } \\
\text { Coefficients }\end{array}$} & \multirow{2}{*}{$\begin{array}{c}\text { Standardized } \\
\text { Coefficients } \\
\text { Beta } \\
\end{array}$} & \multirow[b]{2}{*}{$\mathrm{T}$} & \multirow[b]{2}{*}{ Sig. } \\
\hline \multicolumn{2}{|c|}{ Model } & $\mathrm{B}$ & Std. Error & & & \\
\hline \multirow[t]{3}{*}{1} & (Constant) & 3,757 & 6,039 & &, 622 &, 536 \\
\hline & $\begin{array}{l}\text { X1.Iklan_Media_Elek } \\
\text { tronik }\end{array}$ & ,285 &, 167 & ,240 & 1,705 & ,093 \\
\hline & X2.Endoesement & ,418 & , 185 & ,319 & 2,259 &, 028 \\
\hline
\end{tabular}

a. Dependent Variable: Y.Minat_Beli_Konsumen

\section{Sumber : data diolah menggunakan SPSS 25}

From the table above the multiple linear regression analysis above can be obtained the coefficient for Electronic Media Advertising (b1) of 0.285 , endorsement (b2) of 0.418 , and constant (a) of 3.757. Then the equation is obtained

\section{$Y=3,757+0,285 X_{1}+0,418 X_{2}$}

Based on the above data it can be concluded that the independent variable that has the greatest positive influence on consumers 'buying interest in specs shoes is endorsement that is equal to 0.418 , while the independent variable that has the least positive effect on consumers' buying interest in specs shoes is electronic media advertising that is equal to 0.285 .

Correlation Coefficient Test Results

Simple Correlation Analysis

Simple correlation coefficient analysis to find out how much the relationship that occurs between two or more variables, the correlation between electronic media advertising (X1) on consumer buying interest (Y). Can be seen in the table

Correlation results between electronic media advertisements (X1)

to consumer buying interest (Y)

\section{Model Summary}

\begin{tabular}{cc|c|c|c} 
Model & $\mathrm{R}$ & $\mathrm{R}$ Square & Adjusted R Square & Std. Error of the Estimate \\
\hline 1 &, $436^{\mathrm{a}}$ &, 190 &, 176 & 5,867 \\
\hline
\end{tabular}

\section{a. Predictors: (Constant), X1.Iklan_Media_Elektronik}

Sumber: data yang diolah SPSS 25

From the results of the above calculation it is known that the magnitude of the correlation coefficient (R) of 0.436 then it is known that the relationship between electronic media advertising on consumer buying interest based on interval guidelines has a moderate level of relationship, because the value of 0.436 is in the range of intervals of $0.4400-0.599$. 
The correlation between electronic media endorsement (X2) and consumer buying interest (Y).

\begin{tabular}{ll|l|l|c} 
& \multicolumn{4}{c}{ Model Summary } \\
Model & $\mathrm{R}$ & R Square & $\begin{array}{c}\text { Adjusted R } \\
\text { Square }\end{array}$ & $\begin{array}{c}\text { Std. Error of the } \\
\text { Estimate }\end{array}$ \\
\hline 1 &, $466^{\mathrm{a}}$ &, 217 &, 204 & 5,767 \\
\hline
\end{tabular}

a. Predictors: (Constant), X2.Endoesement

From the calculation above, we know the value of the correlation coefficient $(\mathrm{R})$ of 0.466 , it is known that the relationship between endorsement to consumer buying interest based on interval guidelines has a moderate level of relationship because the value of 0.466 is in the interval range of 0.400 to 0.599 .

Multiple Correlation Analysis

Multiple correlation coefficient analysis is to be able to find out how closely the overall relationship of the independent or independent variables $(\mathrm{X} 1, \mathrm{X} 2)$ with the dependent or dependent variable Results of multiple correlations between electronic media advertisements (X1) And endorsement (X2) on consumer buying interest (Y)

\section{Model Summary}

\begin{tabular}{lr|r|r|r} 
Model & R & R Square & \multicolumn{1}{|c|}{$\begin{array}{c}\text { Adjusted R } \\
\text { Square }\end{array}$} & $\begin{array}{c}\text { Std. Error of the } \\
\text { Estimate }\end{array}$ \\
\hline 1 & $.503^{\mathrm{a}}$ & .253 & .228 & 5.679 \\
\hline
\end{tabular}

a. Predictors: (Constant), X2.Endorsement,

X1.Iklan_Media_Elektronik

From the calculation above, we know the value of the correlation coefficient $(\mathrm{R})$ of 0.503 , it is known that the relationship of electronic media advertising (X1) and endorsement variables (X2) to consumer buying interest (Y) based on interval guidelines has a moderate level of relationship because the value is 0.503 in the interval of $0.400-0.599$.

Determination Coefficient Test Results (KD)

By looking at the R-Square table below it can be seen the value of the coefficient of determination that is equal to 0.253 or $25.3 \%$. This shows that the electronic media advertising variable (X1) and endorsement variable (X2) together affect the consumer buying interest $(\mathrm{Y})$ of $25.3 \%$, and the remaining $74.8 \%$ is influenced by other variables not examined in the study this.

The results of the coefficient of determination between electronic media advertisements (X1) And endorsement (X2) on consumer buying interest (Y)

\section{Model Summary}

\begin{tabular}{l|c|cr|r} 
Model & $\mathrm{R}$ & R Square & $\begin{array}{c}\text { Adjusted R } \\
\text { Square }\end{array}$ & $\begin{array}{c}\text { Std. Error of the } \\
\text { Estimate }\end{array}$ \\
\hline 1 & $.503^{\mathrm{a}}$ & .253 & .228 & 5.679 \\
\hline a. Predictors: (Constant), X2.Endorsement, & & \\
X1.Iklan_Media_Elektronik
\end{tabular}

Partial Test Results $\mathrm{t}$ (T-test)

The statistical test $t$ on is to show how far the influence of one independent variable individually in explaining the dependent variable. Tests carried out by using a significance level of 0.05 ( $\alpha=5 \%)$, namely:

If tcount $<$ ttable, then Ho is accepted and Ha is rejected.

If tcount $>$ ttable, then Ho is rejected and $\mathrm{Ha}$ is accepted.

$\mathrm{T}$ Test Results of Variables

Electronic Media Advertising (X1) and Consumer Purchase Interest (Y)

Coefficients $^{\mathrm{a}}$

\begin{tabular}{|c|c|c|c|c|c|}
\hline \multirow[b]{2}{*}{ Model } & \multicolumn{2}{|c|}{$\begin{array}{l}\text { Unstandardized } \\
\text { Coefficients }\end{array}$} & \multirow{2}{*}{$\begin{array}{c}\text { Standardized } \\
\text { Coefficients } \\
\text { Beta } \\
\end{array}$} & \multirow[b]{2}{*}{$\mathrm{T}$} & \multirow[b]{2}{*}{ Sig. } \\
\hline & $\mathrm{B}$ & Std. Error & & & \\
\hline 1 (Constant) & 11,471 & 5,146 & & 2,229 & ,030 \\
\hline X1.Iklan Media Elektronik &, 516 & 137 & ,436 & 3,779 & 000 \\
\hline
\end{tabular}

a. Dependent Variable: Y.Minat_Beli_Konsumen

From the table above, the t-test results of electronic media advertising variables and consumer buying interest can be concluded that tcount $>$ ttable $(3.779>1.999)$ means that Hal is accepted and Hol is rejected, meaning 
that there is a significant influence between Electronic Media Advertising (X1) on Consumer Purchase Interest ( Y) Shoes Specs.

$\mathrm{T}$ Test Results of Variables

Endorsement (X2) and Consumer Purchase Interest (Y)

Coefficients

\begin{tabular}{|c|c|c|c|c|c|c|}
\hline \multicolumn{7}{|c|}{ Coefficients $^{\mathrm{a}}$} \\
\hline \multirow{2}{*}{\multicolumn{2}{|c|}{ Model }} & \multicolumn{2}{|c|}{$\begin{array}{l}\text { Unstandardized } \\
\text { Coefficients }\end{array}$} & \multirow{2}{*}{$\begin{array}{c}\text { Standardized } \\
\text { Coefficients } \\
\text { Beta }\end{array}$} & \multirow[b]{2}{*}{$\mathrm{T}$} & \multirow[b]{2}{*}{ Sig. } \\
\hline & & $\mathrm{B}$ & Std. Error & & & \\
\hline \multirow[t]{2}{*}{1} & (Constant) & 6,843 & 5,851 & & 1,170 &, 247 \\
\hline & X2.Endoesement & 611 & ,149 & ,466 & 4,112 &, 000 \\
\hline
\end{tabular}

a. Dependent Variable: Y.Minat Beli_Konsumen

Source: data processed using SPSS 25

From the table above the results of the $t$ test of endorsement variables and consumer buying interest note that the tcount is 4.112. With a significance level of 5\%, the 2 -sided test and $\mathrm{df}=\mathrm{n}-2$ or $\mathrm{df}=63-2=61$, so that a thable of 1.999 is obtained so it can be concluded that tcount $>$ ttable $(4.112>1.999)$ means that Ha2 is accepted and Ho2 is rejected, i.e. there is a significant influence between Endorsement (X2) on Consumer Purchase Interest (Y) of Specs Shoes.

Simultaneous Test Results F

Statistical analysis of $\mathrm{F}$ test basically shows whether all the independent variables included in the model have a joint effect on the dependent variable by comparing the calculated $F$ value with the $F$ value according to the table. If the calculated $\mathrm{F}$ value is greater than the table $\mathrm{F}$ value, then Ho is rejected and Ha is accepted.

F Test Results of Electronic Media Advertising Variables and

Endorsement (X2) and Consumer Purchase Interest (Y)

\begin{tabular}{|c|c|c|c|c|c|c|}
\hline \multicolumn{7}{|c|}{ ANOVA $^{\mathrm{a}}$} \\
\hline Model & & $\begin{array}{l}\text { Sum of } \\
\text { Squares }\end{array}$ & Df & Mean Square & $\mathrm{F}$ & Sig. \\
\hline \multirow[t]{3}{*}{1} & Regression & 562,288 & 1 & 562,288 & 16,908 &, $000^{\mathrm{b}}$ \\
\hline & Residual & 2028,569 & 61 & 33,255 & & \\
\hline & Total & 2590,857 & 62 & & & \\
\hline
\end{tabular}

a. Dependent Variable: Y.Minat_Beli_Konsumen

b. Predictors: (Constant), X2.Endoesement

Sumber Data Primer yang diolah dengan SPSS 25

From the table above electronic media advertising variables, endorsement and consumer buying interest, the calculated $\mathrm{F}$ value is 16.908 . With a significance level of $5 \%$, the $\mathrm{F}$ table value is obtained from $\mathrm{n}-\mathrm{k}-1$ namely $(63-2-1=60)$ and the $\mathrm{F}$ table is 3.15. Thus it can be concluded that $\mathrm{F}$ arithmetic $>\mathrm{F}$ table $(16,908>3.15)$, means $\mathrm{Ha}$ is accepted and Ho is rejected, that is there is a positive and significant effect between Electronic Media Advertisements (X1) and Endorsement (X2) together against Interest in Buy Consumer (Y) shoes specs.

\section{CONCLUSION}

Electronic Media Advertising (X1) has a positive and significant influence on Consumer Purchase Interest (Y) of shoe specs in the physical sports store in tangerang city. Based on the results of the $t$ test with the value of $t$ arithmetic $>t$ table $(3.779>1.999)$ with a sig level of $0.000<0.05$. This shows Ha1 was accepted and Ho1 was rejected. that is, there is a significant influence between Electronic Media Advertising (X1) on Consumer Purchase Interest (Y) of Specs Shoes. Endorsement (X2) has a positive and significant influence on Consumer Purchase Interest $(\mathrm{Y})$ of shoe specs at the physical store in Tangerang city sports. Based on the results of $t$ test with tcount $>$ ttable $(4,112>1,999)$ with a sig level of $0,000<0.05$. This shows Hal was accepted and Ho1 was rejected. that is, there is a significant influence between Endorsement (X2) on Consumer Purchase Interest (Y) of Specs Shoes. Electronic Media Advertisements (X1) and Endorsement (X2) together (simultaneously) have a 
positive and significant influence on Consumer Purchase Interest (Y) of shoe specs in the tangerang city sportmall physical store. Based on the results of the $t$ test it can be concluded that the $F$ count $>\mathrm{F}$ table (16.908> $3.15)$ with a sig level of $0.000<0.05$. This shows that Ha3 was accepted and Ho3 was rejected. With the receipt of Ha3, there is a positive and significant influence between the variables of Electronic Media Advertisements (X1) and Endorsement (X2) together on Consumer Purchase Interest (Y) in shoes specs.

\section{Reference}

Alma, Buchari. 2016. Manajemen Pemasaran dan Pemasaran Jasa .Bandung: Penerbit Alfabeta.

Asep Suryana. 2016. Komunikasi Pemasaran. Tangerang: Penerbit Universitas Terbuka.

Donni Juni Priansa. 2017. Komunikasi Pemasaran Terpadu (Pada Era Media Sosial). Bandung: CV Pustaka Setia.

Fandy Tjiptono. 2015. Strategi Pemasaran. Edisi 4. Yogyakarta: Penerbit Andi

Ghozali, Imam. 2017. Aplikasi Analisis Multivariete dengan Program IBM SPSS 21. Semarang: Badan Penerbit Undip.

Hasan, Ali. 2013. Marketing. CAPS (Center For Academic Publishing Service). Yogyakarta.

J, Suptanto. 2012. Metode Riset (Aplikasinya dalam Pemasaran). Jakarta: Rineka Cipta

Kertamukti, Rama. 2014. Strategi Kreatif dalam Periklanan (Konsep Pesan, Media, Branding, Anggaran). Jakarta: Rajawali Pers.

Kotler, P \& Keller, K, L. 2016. Manajemen Pemasaran. Edisi 13, Jilid 1.Jakarta: Erlangga.

Shimp, Terrence A. 2014. Komunikasi Pemasaran Terpadu dalam Periklanan dan Promosi. Jakarta. Salemba Empat.

Sugiyono. 2016. Metode Penelitian (Kuantitatif, Kualitatif, dan R\&D). Bandung: Penerbit Alfabeta. 